\title{
The Quranic Consonantal Text: Phonology
}

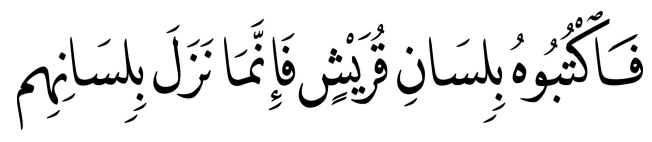

SUṬMĀN B. SAFFĀN

\subsection{Introduction}

It has long been recognized that the orthography of the QCT, in principle reflects the phonology of Hijazi Arabic. Most notably the way that the hamzah is (not) spelled, seems to reflect the purported loss of this sound in the Hijazi dialect. While some authors see this tendency of the orthography as a purely orthographic convention, envisioning that the actual language of the Quran was pronounced with the non-Hijazi pronunciation with hamzah (e.g. Zwettler 1978, 124; Versteegh 2014, 64) others do not express a clear opinion to what extent the Hijazi orthography can reveal anything about the language of the Quran itself (e.g. Diem 1976; 1979). However, Rabin (1951, 3f.) (also Nöldeke 1904, 11; and Blau 1977, 15f.) is quite confident that the orthography in fact reveals something about the way the Quran was actually pronounced, saying "the pronunciation of the literary language was of course largely accommodated to their native dialect, to which the Koran spelling is therefore a fairly reliable guide." On other occasions, Rabin likewise expresses that the orthography is to be taken seriously for the phonetics of Quranic Arabic. I agree with this view, and I believe that the correctness of this assumption is confirmed to a large extent by the Quranic rhyme (see van Putten 2018). Indeed, whenever the rhyme allows us to examine the presence of the hamzah, for example, we must conclude that it was in fact not there whenever the orthography suggests its absence. Thus شان (Q55:29) breaks the strict |-ān| rhyme of Sūrat al-Rahmmān if read as $\check{s} a ? n$, whereas this problem is resolved if read as /šān/, the same is clear for شيا (Q19:9) which breaks the rhyme when read as šay?ā but is perfectly consistent with the |-i/ayyā| rhyme if read as /šayyā/ or /šiyyā/. The QCT thus clearly reveals a hamzah-less pronunciation. To understand the linguistic nature of the 
language of the Quran, we must let the text tell us, rather than impose a set of mutually contradictory norms presented by the canonical reading traditions.

This chapter will look at some of the phonetic isoglosses that can be deduced from the QCT, in order to connect them with the phonetic features discussed by the grammarians. Some of the features discussed here are isoglosses that Rabin considered part of morphology. While these indeed have an effect on the morphology, they are the outcome of regular sound laws, and therefore I choose to discuss them here. Here too, we will compare the isoglosses to those found in Northern Old Arabic like Safaitic and Nabataean Arabic, showing that several important innovative features are indeed unattested in northern varieties, while they are attested in the QCT.

There are several phonetic isoglosses of the QCT that do not get explicitly referred to as Hijazi features according to the grammarians. Most of the time grammarians do discuss such features, as one of the goals of the grammatical works was to account for the language of the Quran. Even when there is a lack of attribution from the grammarians of certain features to the Hijaz, Rabin (1951) frequently attributes these features to the Hijaz by virtue of them being present in the Quran. This is circular, and rather surprising as Rabin often expresses skepticism of any attribution to Hijazi Arabic when medieval grammarians cite the Quran as evidence for it (as he does, for example in the dālika rather than $\underline{d} \bar{a} k a$ isogloss, see $\S 4.3$ above). We will only count features as confirmed to be part of Hijazi Arabic whenever it is explicitly done so by the Arab grammarians, or epigraphic evidence suggests that the innovation is at least absent in Northern Old Arabic. It should be noted, however, that the grammarians report linguistic data from a not insignificant time after the composition of the Quran. As a result, it is possible that when data reported by the grammarians does not align with the QCT being Hijazi, this could still rather be the result of a difference in time, rather than a true disagreement. Often it is not possible to prove this with any certainty, but at times papyri and early Islamic epigraphy may yield some insights.

As Rabin (1951, 130, §l,m,n) says: "the most celebrated feature of the Hijaz dialect is the disappearance of the hamza, or glottal stop." Indeed, this is a feature universally attributed to the Hijaz by the Arab grammarians, and it is widely recognized to be the foundation for the Islamic Arabic orthography (Diem 1976). Van Putten (2018) argues that, not only does a ?-less dialect form the basis of the orthography of the QCT, but the Quranic rhyme confirms that 
the orthography is, in fact, an accurate representation of the Quranic Arabic phonology and therefore had lost $?$ in almost every position. The table below summarizes the evidence of the loss of hamzah that can be derived from the Quranic rhyme. First listing the QCT spelling, and the readings, and finally the reconstructed reading that is consistent with the rhyme context it occurs in.

\begin{tabular}{|c|c|c|c|c|}
\hline & QCT & Reading traditions & Reconstructed reading & Rhyme \\
\hline$Q_{55: 29}$ & 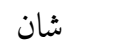 & ša?nin, šānin & /šān/ & $|-\bar{a} N|$ \\
\hline Q69:9 & بانلاطيه & bi-l-xāți?ati, bi-l-xāțiyah & /bi-l-xāțiyah/ & |-āCiyah \\
\hline Q96:16 & خاطيه & xāṭi?atin, xāțiyatin & /xāțiyah/ & |-āCiyah \\
\hline Q19:9, 42, 6o, 67 & شيا & šay?an & /šayyā/ (or /šiyyā/) & |a/iyyā $\mid$ \\
\hline Q19:30, 41, 49, 51, 53, 54, $5^{6}$ & 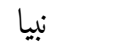 & nabট̈?an, nabiyyan & /nabiyyā/ & |a/iyyā $\mid$ \\
\hline Q19:74 & وريا - إ - إ & wa-ri?yan, wa-riyyan & /wa-riyyā/ & |a/iyyā $\mid$ \\
\hline
\end{tabular}

One exception to this general loss seems to have been the word-final ?alif mamdüdah (i.e. $-\bar{a}$ ?) which appears to have retained some phonetic trace of the *?, either as stress + hiatus, or indeed a true glottal stop realization (see Van Putten 2018: 103-105). Rabin (1951, 141, §ee) alludes to the possibility that this may be a place where the Hijaz retained the hamzah whereas eastern dialects lost it. Later lexicographical works shows some lexical items with Hijazi $-\bar{a}$ ? corresponding to eastern $-\bar{a} /-\bar{e}$ but among the early grammarians I have only found evidence for this correspondence in the plural deictic which is said to be $h \bar{a} ? u-$ $l \bar{a} P i$ in the Hijaz while it is $(h \bar{a})-? u l \bar{a} / \bar{e}$ in the eastern dialects (see $\S 4.4)$.

Despite an almost universal attribution of hamzah-loss to the Hijaz by later grammarians, neither Sībawayh nor al-Farrā? are very explicit in attributing this loss to the Hijaz. Sïbawayh gives a detailed account in the manner that the hamzah may be lost in Arabic (Sïbawayh IV, $541 \mathrm{ff}$.), but at no point does he attribute this dropping specifically to the Hijaz. The developments he discusses are clearly similar to those suggested by Van Putten (2018) and Diem (1980) to have taken place in the (orthography of) the QCT. However, to Sỉbawayh this form of dropping of the hamzah was acceptable within what he considered Sarabiyyah, and the highly conservative application of the hamzah so closely associated with Classical Arabic today, does not seem to have been the stereotypical feature of proper Arabic in his time. Al-Farrā? does not explicitly attribute the complete loss of hamzah to the Hijaz either, but when we examine the cases where he does attribute the loss of hamzah to certain tribes, it is invariably to the people of the Hijaz or Qurayš. If we were to generalize 
these isolated statements (something that is not necessarily warranted, nor explicitly unwarranted from the structure of the text), we indeed end up with all the developments typically associated with the Hijazi hamzah-loss, and a situation that closely matches the QCT. The list below is a comparison of what is reported in terms of hamzah-loss in al-Farrā?'s Lugāat al-Qur?ān.

- mustahzi?ūna > mustahzūna (Qurayš and the common people of Ġațafān and Kinānah, p. 15); QCT مستקزون (Q2:14)

- sayyi?ah > sayyah, sayyiyah (People of the Hijaz, p. 30); QCT سييه (Q2:81). The collapse of the yyiy sequence to yy seems to take place in the plural السيات (passim)

- Panbirū-nī > Panbū-nī (Qurayš, p. 22); QCT انبونى (Q2:31).

- is?al > sal (People of the Hijaz, p. 34); QCT سل (Q2:211 and passim).

- rid?an > ridan (People of the Hijaz, p. 113); QCT اد (Q28:34).

- rilyan > riyyan (People of the Hijaz, p. 90); QCT ريا (Q19:74).

- al-minsa?ah, >al-minsāh (People of the Hijaz, p. 119, cf. MaSānīal-Qur?ān, II, 256); QCT منسته (Q34:14).

- at-tanā?uš > at-tanāwuš (People of the Hijaz, p. 119, cf. MaSānīal-Qur?ān, II, 365); QCT التنوش (Q34:52).

To this we may add the following Isolated statements in his MaSānīal-Qur?ān: - yakla?u-kum > yaklawu-kum, yaklā-kum (Qurayš, vol. II, p. 204); QCT يكوك (Q21:42).

Al-Farrā?'s statements therefore seem to confirm the conclusion that the Hijazi dialect lacked hamzah.

The loss of hamzah is a Hijazi feature to the Arab grammarians, and this seems to be corroborated by the epigraphic record. The northern varieties of Nabataean, Safaitic (as well as Hismaic) perfectly retain the hamzah in all positions (e.g. Al-Jallad 2015, 45, 53; van Putten 2018, 96). This is especially relevant in the case of Nabataean Arabic. As the Nabataean script is the one ancestral to the modern Arabic script, the difference in orthographic practice between Nabataean Arabic and the QCT is striking. We find that Nabataean Arabic consistently employs the ?alif to denote the hamzah, even in places where in the QCT it would go unwritten or would be written with a glide. The fact that the QCT's orthography differs appreciably in this regard and abandons manners of writing the hamzah in favour of hamzah-less spellings is a strong indication of an orthographic innovation to accommodate the vernacular.

1 Al-Farrā? that al-PaYmaš and Yāṣim read with hamzah, but that without hamzah is more wellformed for recitation (?ahya? u fi l-qirāiah), a nice example of an explicit endorsement of a hamza-less form. This opinion of al-Farrā? is no doubt inspired by the fact that riyyan is better in line with the rhyme of this Sürah than the reading riryan. 


\subsection{Development of the Phoneme $\bar{o}$}

Quranic Arabic has several cases where a mater lectionis wāw is used where all

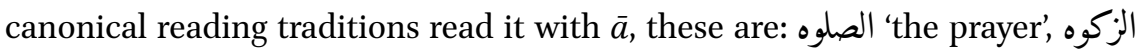
'alms', الحيوه 'the life', منوه 'Manāt (pre-Islamic goddess)', النجوه 'the salvation', الغدوه 'morning'. Modern scholars have generally taken these as purely orthographic idiosyncrasies of these words - often suggested to be inspired by Aramaic - and assumed they simply had a vowel $\bar{a}$ as in Classical Arabic, but as the Arabic roots clearly have a distinct etymological origin (containing a " $w$ in the root) and predictable phonetically conditioned behaviour, it seems more likely that these words in fact had a long vowel $/ \overline{\mathbf{o}} /$ in the final syllable, that is /aṣ-șalōh/, /az-zakōh/, /al-ḥayōh/, /manōh/, /an-nağōh/, /miškōh/ and /al-ġadōh/ (Al-Jallad 2017c; van Putten 2017a).

There are good QCT-internal and comparative reasons to see this as an innovation of Quranic Arabic, for example Safaitic still retains an original triphthong here $n g w t$ /nagawat/ 'salvation' (Al-Jallad \& Jaworska 2019, 102), also the Arab grammarians clearly saw this pronunciation for specifically these words as typical for the Hijaz, as opposed to the pronunciation with /â/ found elsewhere. Sibawayh (IV, 432), for example, calls it "the ?alif al-tafxim, by which is meant the linguistic practice of the people of the Hijaz in their speech of as şalōh, az-zakōh and al-hayōh." This statement has often been taken to mean that all cases of $/ \bar{a} /$ where pronounced backed/rounded by the people of the Hijaz, or word-final stressed /ā/ was (e.g. Rabin 1951, 105f.; Testen 2005, 219), but this is not in keeping with the evidence. The feminine plural $-\bar{a} t$ is never spelled with wāw nor are nouns of the shape CaCāC, CiCāC, CuCāC etc. The fact that Sībawayh specifically cites the words that are spelled with a wāw in the QCT, and not any other words suggests that it is words specifically of this type, i.e. original ${ }^{*}$ CaCawat- nouns that undergo this shift.

\subsection{Lack of $C y \bar{\imath}>C \bar{\imath}$}

Al-Farrā? (Lug $\bar{a} t, 21)$ reports that the Qurayš and commonly among the Arabs yastahy $\bar{\imath}$ is pronounced with the expected $y \bar{\imath}$ sequence, but Tamim and Bakr b. Wā?il read it yastahī. While the modern Cairo Edition text agrees with the Tamìmì form, this is an idiosyncrasy of the print edition. The QCT as it is reflected in early Quranic manuscripts consistently agrees with the common form also found among the Qurayš, e.g. يستحيى (Q2:26) يحيى (Q2:258) (for a further discussion, see Appendix A.2.2). 


\subsection{Passive of Hollow Verbs}

The passive perfect of hollow verbs had three forms. In the Hijaz qĩla, with the Qays and part of Pasad dialect with a front rounded vowel qüla and qüla among the Tamīm, FaqTas and Dabr (§ 2.2.2.5; Rabin 1951, 159, §t; al-Farrā? Luġāt, 14). ${ }^{2}$ These are different dialectal outcomes of what in Proto-Arabic was probably still a triphthong *quwila. ${ }^{3}$ The QCT aligns with the Hijazi form, e.g. قيل (Q2:11 and passim).

\subsection{Retention of șirāt}

Al-Farrā? (Lug்āt 9 f.) tells us that the word șirāt 'road' is the form used by the Qurayš, while other pronunciations exist:

- sirāț, a reading attributed to Ibn Sabbās

- Qays is supposed to have pronounced it with the initial sound in between $s$ and $s .^{4}$

- zirāt, a reading he attributed to Hamzah ${ }^{5}$ and the tribes of Gudrah, Kalb and Banū Qayn.

Al-Farrā? points out the QCT explicitly agrees with the Qurashi form: "as for الصراط, there are four linguistic practices: the perfect practice is the first practice of the Qurayš, which is what the book (the Quran) brings (written) with a șād." Indeed 'path' is always spelled صر ط, الصرط in the QCT.

The grammarians seem to have considered the form sirāt the original and the Qurayš form the result of emphasis spread, but from an etymological perspective this is to be doubted. ${ }^{6}$ This word being a loan from the Latin strata (presumably through Greek and Aramaic), it seems that the $s$ was used as a

2 Sibawayh (IV, 342 f.) discusses these forms but does not attribute the forms to specific tribes.

3 Other triphthongs such as $a w i$, awu, awa appear to have not yet collapsed in Proto-Arabic as Safaitic generally retains them (Al-Jallad 2015, $119 \mathrm{f}$.).

4 This might be seen as further corroboration that Al-Jallad (2014a) is right to see Sībawayh's description of the șād as an affricate, and that this description should be seen as endorsing a pronunciation that is an emphatic sibilant șâd, as it is pronounced in modern dialects today.

5 In modern recitation, Ḥamzah's reading is said to be pronounced in between șād and $z \bar{a} y$, which in practice means it is pronounced as an emphatic $z$, i.e. [ $\left.\mathrm{z}^{\mathrm{S}}\right]$ (Ibn Muğāhid 105-107; Ibn al-Ǧazarī § 1119).

6 See for example Lisān (1993b) which says șirāt is a dialectal form (lugah) and that sirät is the origin (Pașl). This seems to be mirrored in other lexicographical works, as Lane (1348c) mirrors the same perspective from several sources. 
means to represent the cluster st. This strategy is found elsewhere in Arabic, for example in qașr < Lat. castrum. ${ }^{7}$ The Qurayš form should therefore probably be considered a retention, rather than an innovation.

\subsection{Lack of Syncopation of * $u$ and ${ }^{*} i$}

Hijazi was known for its conservative syllable structure compared to Najdi. As discussed in $§$ 2.2.4, whenever two short syllables follow, and the second contains a high vowel $u$ or $i$, it would syncopate, while Hijazi retains such forms. Basic noun formations affected by this are the following:

\begin{tabular}{ll}
\hline Hijaz & Najd \\
\hline $\mathrm{CuCuC}$ & CuCC \\
$\mathrm{CiCiC}$ & $\mathrm{CiCC}$ \\
$\mathrm{CaCuC}$ & $\mathrm{CaCC}$ \\
$\mathrm{CaCiC}$ & $\mathrm{CaCC}$ \\
$\mathrm{CuCiC}$ & $\mathrm{CuCC}$ \\
$\mathrm{CaCiCah}$ & CaCCah \\
CaCuCah & CaCCah \\
\hline
\end{tabular}

Due to the QCT not recording short vowels, it is difficult to be entirely sure what the status of the syllable structure is in Quranic Arabic, however words of this type occasionally stand in rhyming position, which lets us make some deductions about the application of this syncopation.

However, as we can only examine these forms in rhyme, another complication is added to this examination, as Sībawayh (IV, 173 ff.) reports that "some Arabs" would insert vowels to break up final CC-clusters in pause. In CaCC nouns the nominative and genitive are inserted giving hä $\underline{d} \bar{a}$ bakur\# (for bakrun) and wa-min bakir\# (for bakrin). Sībawayh does not explicitly state what

7 This borrowing strategy should either be understood as the ș still being an affricate at the time these words were borrowed and $\left[{ }^{{ }^{\mathrm{S}} \mathrm{S}}\right]$ being considered the closest equivalent to [st]. But alternatively it may be the case that these words entered Hijazi Arabic through a dialect where the reflex of Proto-Arabic *s was [st] or [șt], much like some of the modern dialects of the Saidah region in Yemen today (Behnstedt 1987, 7). 
happens to the accusative, except that the $a$ is not inserted. For the indefinite one of course gets bakrä\# (for bakran), but for al-bakra it is unclear, perhaps it is optionally to be read as al-bakir\# or al-bakur\# (see Sïbawayh, IV, 174, l. 3). For CiCC and CuCC nouns it is clear that the vowel simply harmonizes with the preceding vowel, and the case vowel has no effect: hä $\underline{d} \bar{a}$ Sidill (< Sidlun) or fisil\# (< fislun), fil-busur\# (for busrin), ra?aytu l-Sikim\# (for al-Sikma), ra?aytu l-ğuhur\# (al-ğuhra). While Sïbawayh does not explicitly attribute these forms to a certain dialect, he does mention that those who insert vowels in those cases are those who weaken al-busuru to al-busru in context; these are the Najdi dialects, and it therefore seems clear that this is an eastern practice, not part of Hijazi Arabic. Therefore, comparing the Hijazi to Najdi forms in pause we would expect the following reflexes.

\begin{tabular}{|c|c|c|c|c|}
\hline & Hijaz & & Najd & \\
\hline & Context & Pause & Context & Pause \\
\hline $\mathrm{CaCC}$ & bakrun & bakr\# & bakrun & bakur\# \\
\hline $\mathrm{CiCC}$ & Sidlun & Sidl\# & Sidlun & Sidil\# \\
\hline $\mathrm{CuCC}$ & ğuhrun & ğuhrr\# & ğuhrun & ğuḥur\# \\
\hline CaCiCan & kadiban & kadibā\# & kadban & $k a \underline{d} b \bar{a} \#$ \\
\hline CaCuCan & rağulan & rağulā\# & rağlan & rağlā\# \\
\hline $\mathrm{CuCuC}$ & busurun & busur\# & busrun & busur\# \\
\hline CuCuCan & busuran & busurāa\# & busran & busrā\# \\
\hline $\mathrm{CiCiC}$ & Pibilun & Pibil\# & Piblun & Pibil\# \\
\hline CiCiCan & Pibilan & Pibilā\#\# & Piblan & Piblā\# \\
\hline
\end{tabular}

It is not clear how CaCiCun and $\mathrm{CaCuCun}$ nouns would behave in the Najdi dialects as Sibawayh does not explicitly discuss them, but it seems likely that the etymological vowel would simply return in such environments in pause.

Now if we turn to the Quranic rhyme, we can make some predictions on which forms can rhyme with which, depending on whether the Quran had Najdi or Hijazi style syllabification. If Quranic Arabic had Najdi style syllabification, one would expect original $\mathrm{CvCiCa}, \mathrm{CvCuCa}$ to rhyme freely with CvCCā, while in Hijazi syllabification these would be expected to remain distinct.

Moreover, due to the probable lack of epenthesis in CC-clusters in pause in Hijazi, it seems likely that if the Quran had Hijazi syllabification that non- 
indefinite accusative $\mathrm{CvCiC}$, and $\mathrm{CvCuC}$ nouns should not rhyme freely with CvCC nouns. Indeed, on examining the different rhymes in the QCT, we find a distribution that is consistent with Hijazi syllabification.

\subsection{1 vCCā Rhymes}

There are many examples of indefinite accusative rhymes where the preceding sequence is consistently a long consonant or a consonant cluster. These, as a rule, do not rhyme with words where one expects a vowel in between the two consonants in Hijazi. There are a few exceptions to this among the Quranic reading traditions, most of which can be explained, and these will be discussed below. Sequences with a consonant cluster indefinite accusative rhyme are: Q18:65-83; Q19:76-98; Q20:97-115; Q37:1-3; Q51:1-4; Q65; Q77:1-6; Q79:1-5; Q80:25-31; Q100:1-5.

\subsection{2 vCā Rhymes}

vCCā rhymes are clearly distinct from rhymes that do not have a consonant cluster before the indefinite accusative ending and thus rhyme in vCā. Examples of this type of rhyme are: Q18:1-64 and $Q_{72}$.

\subsection{3 vCC Rhymes}

Rhymes in a consonantal cluster vCC are relatively rare, but common enough that their lack of rhyming with $\mathrm{vC}$ rhymes seems consistent. Examples are Q77:32-33, Q86:11-14, Q89:1-5; Q97; Q103.

\subsection{4 vC Rhymes}

vC rhymes are relatively rare, only showing up in Q51:7-9 and the whole of Q54. The rhyming patterns in Q54 are especially telling. Word-final geminates are treated as a single consonant, and thus al-qamar (Q54:1) may rhyme with mustamirr (Q54:2).

\subsubsection{Discussion}

The general pattern of these rhymes is clear: as a rule $u$ and $i$ were not syncopated, following the Hijazi Arabic practice. This is clear for nouns that end in aCiC or aCuC, which can be seen in the table below. Counterexamples to this pattern do not exist. While aCi/uC rhymes not followed by the indefinite accusative would likely have this shape in Najdi as well due to the epenthesis discussed above, we would expect such cases to rhyme freely with aCC nouns, which they do not. 


\begin{tabular}{|c|c|c|}
\hline Unsyncopated word & Preceding rhyme & Following rhyme \\
\hline كذبا /kadibā/ (Q18:5) & / ولدا / waladā/ & اسفا /Pasafā/ اسفا \\
\hline كذبا /kadibā/ (Q18:15) & شططا /šaṭațā/ & /mirfaqā/ or /marfiqā/8 مرفقا \\
\hline رجلا /rağulā/ (Q18:37) & /munqalabā/ & احدا / Rahạadā/ \\
\hline مقتدرا /muqtadirā/ (Q18:45) & & Xol/Ramalā/ \\
\hline | عذدا / عaḍudā/ (18:51) & بدلا /badalā/ & / موبقا /mawbiqā/ مو/ \\
\hline كذبا /kadibā/ (Q72:5) & إططا /šațațā/ & رهقا رهahaqā/ \\
\hline منتشر/muntašir/ (Q54:7) & ك /nukur/10 & | \\
\hline / fa-ntașir/ (Q54:10) فانتصر & | & / منهمر /munhamir/ \\
\hline مدكز /muddakir/ (Q54:15) & |kufir/ كفر/ كف & ا نذر /nudur/ \\
\hline مدكز /muddakir/ (Q54:17) & نذر /nudur/ & انذر /nudur/ \\
\hline منقعر/munqaYir/ (Q54:20) منع & / / مستمر / & نذر /nudur/ \\
\hline مدكر /muddakir/ (Q54:22) & نذر /nudur/ & | \\
\hline الاشر /al-ašir/ (Q54:26) & 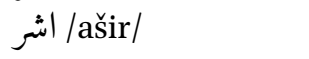 & | \\
\hline /al-muhtazir/ (Q54:31) المتظر / & | نذر /nudur/ & مدك /muddakir/ \\
\hline مدكر /muddakir/ (Q54:40) & | لذر /nudur / ن & | نذر /nudur/ \\
\hline مقتدر /muqtadir/ (Q54:42) مقد & | نذر /nudur/ & | laz-zubur/ الزبر / ال \\
\hline ) منتصر /muntașir/ (Q54:44) & الزبر/az-zubur/ & | الدبر/ad-dubur/ الد / \\
\hline مدكر /muddakir/ (Q54:51) & | & الزبر /az-zubur/ \\
\hline ) مقتدر /muqtadir/ (Q54:55) & نهر/nahar/ & \\
\hline
\end{tabular}

For some of the readers waladā seems to rhyme with CvCCā stems in some contexts and $\mathrm{CaCaCa}$ in others. ولدا occurs seven times in rhyme position, three times in an expected CaCaCā rhyme, and four times in a CvCCā rhyme. However, when look at the other reading traditions, we find that in the CvCCā rhyme, Hamzah and al-Kisāî̀ read this word as wuldā in the places where the rhyme seems to conflict (Ibn al-Ğazarī, § 3570). The table below tabulates the words in their context.

8 Ibn al-Ǧazarī (\$ 3489$)$.

$9 \quad$ Also read as $\{u q b \bar{a}$, see discussion below.

10 Also read as nukr, see discussion below. 


\begin{tabular}{|c|c|c|}
\hline & Preceding rhyme & Following rhyme \\
\hline ولدا /waladā/ (Q18:4) & ابدا /abadā/ & كذبا /kadibā/ \\
\hline ولدا /waladā/ (Q18:39) & احدا /aḥadā/ & | طلبا /țalabā/ \\
\hline /ولدا /waladā/ (Q72:3) & احد| /aḥadā/ & كذبا /kadibā/ \\
\hline ولدا /wuldā/ (Q19:77) & / مردا /maraddā/ & | عهدا / عahdā/ \\
\hline ولدا /wuldā/ (Q19:88) & | عهد/ / عahdā/ & ادا /iddā/ \\
\hline ولدا /wuldā/ (Q19:91) & هد / هد /haddā/ & /ولدا /wuldā/ \\
\hline ولدا /wuldā/ (Q19:92) & /ولدا /wuldā/ & | عبد/ / عabdā/ \\
\hline
\end{tabular}

There are two cases in Q18, where the rhyme word seems to conflict, where we find a word universally read as CvCCā in both cases flanked by CaCaCā, these are تَعا /tisfā/ (Q18:25; preceding rhyme /rašadā/ and following rhyme /ahadā/) and زرعا/zarYā/ (Q18:32; preceding rhyme /murtafaqā/, following rhyme /naharā/). Both of these words end in $\$$, and one wonders whether there was a vocalic epenthesis under the influence of this guttural to yield /tisafâ/ and /zarafā/. In the case of Q18:32 another solution, however, may simply be that the verse does not end there. According to the Meccan and old Medinan verse count زرعا is not the end of the verse (Spitaler 1935, 42).

\subsubsection{Alternation between $\mathrm{CuCuC}$ and $\mathrm{CuCCNouns}$}

Remaining exceptions are primarily found with nouns of the shape $\mathrm{CuCuC}$ or $\mathrm{CuCC}$, where in several cases the rhyme suggests that Quranic Arabic had the shape $\mathrm{CuCuC}$, but CuCCā for the indefinite accusative, i.e. following a syncopation and epenthesis model that is more similar to what is reported for Najd. However, not all nouns with the $\mathrm{CuCuC}$ shape seem to behave this way, which makes it difficult to evaluate the evidence.

Several $\mathrm{CuCuC}$ nouns, from their rhyme context should clearly be understood as non-syncopating in all contexts. For some of these words, several of the readers adhere to $\mathrm{CuCC}$ readings, but it seems evident from the rhyme that this is not the correct reading. 


\section{Preceding rhyme Following rhyme}

\begin{tabular}{|c|c|c|}
\hline جرزا /ğuruzā/ (Q18:8) & لع / / Yamalā/ & | عجبا / \\
\hline فرطا /furuțā/ (Q18:28) & | ملتحدد /multaḥadā/ & إmurtafaqā/ مرتفقا / \\
\hline حقبا /ḥuqubā/ (Q18:6o) & / موعدا /mawYidā/ & | سربا /sarabā/ سربا \\
\hline شهبا /šuhubā/ (Q72:8) & احدا / Raḥadā/ & رصدا /rașadā/ \\
\hline $\begin{array}{l}\text { لقب /qubulā/ (Q18:55) } \\
\text { /qibalā/ Nāfî, Ibn Kat̄īr, Pabū Yamr, Ibn Yāmir, YaYqūb } \\
\text { (Ibn al-Ǧazarī § 3514) }\end{array}$ & | جدلا / ğadalā/ & ا هزوا /huzuwā/ \\
\hline $\begin{array}{l}\text { هزو /huzuwā/ Hafṣ (Q18:56) } \\
\text { /huz?ā/ Hamzah, Xalaf } \\
\text { /huzwā/ Ḥamzah on pause } \\
\text { /huzu?ā/ Rest (Ibn al-Ǧazarī § 2667, 2670). }\end{array}$ & قبلا /qubulā/, /qibalā/ & ابدا /abadā/ \\
\hline هزوا /huzuwā/, /huzPā/, /huzwā/, /huzuPā/ (Q18:106) & | وزنا /waznā/ & ززلا /nuzulā/ \\
\hline $\begin{array}{l}\text { رعبا /ruYbā/ (Q18:18) } \\
\text { /ruYubā/ Ibn Yāmir, al-Kisā?̄̄i, Pabū ĞaSfar, YaYqūb } \\
\text { (Ibn al-Ğazarī, §2677) }\end{array}$ & | & احدا / Raḥ̣adā/ \\
\hline $\begin{array}{l}\text { عقبا / Yuqubā/ (Q18:44) } \\
\text { /Yuqbā/ Yāșim, Hạamzah, Xalaf (Ibn al-Ǧazarī, § 2684) }\end{array}$ & | منتصرا /muntașirā/ & | مقتدرا /muqtadirā/ \\
\hline ودسر /wa-dusur/ (Q54:13) & | ق قدر /qudir/ & كفر/kufir/ \\
\hline وسعر /wa-suSur/ (Q54:24)11 & / بالنذر /bi-n-nudِur/ & اشر /ašir/ \\
\hline الزبر /az-zubur/ (Q54:43) الزب & | & | \\
\hline 㑭/wa-d-dubur/ (Q54:45) & | lmuntașir/ & | وامر/wa-Pamarr/ \\
\hline
\end{tabular}

In two cases, however, rhyme seems to suggest a pronunciation with $\mathrm{CuCuC}$ in every form but the indefinite accusative, where the indefinite accusative is CuCCā with syncope in the indefinite accusative. In the case of nudur 'warnings' the nudur/nudrā alternation is agreed upon by all readers, but for nukur 'denial' the nukur/nukrā alternation is disagreed upon by the readers, although the majority also has nukur/nukrā as the rhyme suggests. 


\section{Preceding rhyme Following rhyme}

\begin{tabular}{|c|c|c|}
\hline النذر /an-nudur / (Q54:5) الن & |muzdağar/ & نكukur/, /nukr/ \\
\hline 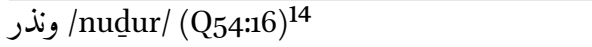 & مدك /muddakir/ & مدكز مداك /mudakkir/ \\
\hline نذر /nudِrā/ (Q77:6) & 1 ذَjikrā/ & اقو /lawāqi؟/ لوق \\
\hline ن ن /nukur/ (Q54:6) & النذر /an-nudِūr/ & | \\
\hline \multicolumn{3}{|l|}{ /nukr/ Ibn Kat̄īr (Ibn al-Ǧazarī, § 2688) } \\
\hline انك /nukrā/ (Q18:74) & عسرا / عusrā/ (Q18:73) & | صبرا/ṣabrā/ \\
\hline /nukurā/ Nāfiৎ, Ibn Dַakwān San Ibn Yāmir, & /Yusurā/ Rabū Ǧaffar & \\
\hline $\begin{array}{l}\text { ŠuYbah Yan Yāșim, Pabū ǦaYfar, YaYqūb (Ibn } \\
\text { al-Ǧazarī, § 2685) }\end{array}$ & (Ibn al-Ǧazarī, § 2674) & \\
\hline انكر /nukrā/, /nukurā/ (Q18:87) & حسنا /husnā/ & إسرا /yusrā/, /yusurā/ \\
\hline I نكukurā/, /nukrā/ (Q65:8) & إسرا/yusrā/, /yusurā/ & | خسرا /xusrā/ \\
\hline
\end{tabular}

Finally, the nouns $n u z(u) l$ 'lodging' and $y u s(u) r$ 'ease' occur in environments where the reading /nuzlā/ and /yusrā/ seems to work best for the rhyme, and others where /nuzulā/ and /yusurā/ work better.

\begin{tabular}{|c|c|c|}
\hline & Preceding rhyme & Following rhyme \\
\hline نزلا /nuzulā/ (Q18:102) & سمعا /samfā/ & صن /ṣunfā/ (Q18:104) \\
\hline نزلا /nuzulā/ (Q18:107) & $\begin{array}{l}\text { ا هزو/huzuwā/, /huz?ā/, } \\
\text { /huzwā/, /huzu?ā/ }\end{array}$ & ال حولا /hiwalā/ \\
\hline $\begin{array}{l}\text { اسـرا /yusrā/ (Q18:88) } \\
\text { /yusurā/ Pabū ǦaSfar (Ibn al-Ǧazarī, § 2674) }\end{array}$ & 1:ك ن /nukurā/, /nukrā/ & سببا /sababā/ \\
\hline إسرا /yusrā/, /yusurā/ (Q51:3) & | وقرا /wiqrā/ & امرا /amrā/ \\
\hline يسرا /yusrā/, /yusurā/ (Q65:4) & قدرا /qadrā/ & اججا /ağrā/ \\
\hline يسرا /yusrā/, /yusurā/ (Q65:7) & اخرى /uxrē/ & نكا /nukurā/, /nukrā/ \\
\hline
\end{tabular}

This conflicting evidence does not allow for a simple resolution, and from a broader Semitic perspective, it is not easy to solve this either. In other Semitic

\footnotetext{
13 See also Q54:41.

14 See also Q54:21, 23, 30, 37, 39.

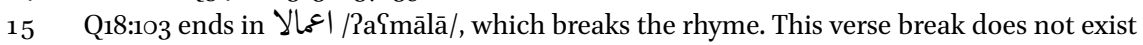
for the Meccan, or either of the Medinan verse counts (Spitaler 1935, 43).
} 
languages, nouns with the shape $\mathrm{CuCuC}$ are excessively rare (Fox 2013, 203 ff.). Fox $(2013,205)$ suggests this may have been the shape of the infinitive construct in Hebrew, e.g. qatol < "qutul-, while *qtul- has also been suggested (Suchard 2019, 246). Besides this, only the isolated nouns bokor 'first-born' (cf. Syr. bǔkur, bukrā) and hălom 'dream' (cf. CAr. hulum, hulm) seem to point to such a noun shape.

Arabic $\mathrm{CuCuC}$ nouns often have byforms with the shape $\mathrm{CuCC}$ (generally attributed to eastern dialects by the grammarians), but frequently correspond to formations in other Semitic languages that unambiguously point to CuCC. For example, fractions like such as rubuৎ, rubs 'fourth' and xumus, xums 'fifth' correspond to Hebrew roba $\{$ 'fourth' and homeš 'fifth'; the Hebrew forms unambiguously point to "rubs-and "xums ${ }^{1-}$. A similar conflict is found with CAr. Pudun, ?udn 'ear', Hb. Pozen < *?udn. For this reason, many authors (e.g. Rabin 1951, 97f.; Fox 2013, 150) have suggested that these forms are the result of dialects with vocalic epenthesis of ${ }^{*} \mathrm{CuCC}>\mathrm{CuCuC}$ and in other cases syncope ${ }^{*} \mathrm{CuCuC}>\mathrm{CuCC}$. However, this cannot entirely account for the variation that we see.

In the Arabic as described by the early grammarians, $\mathrm{CuCuC}$ and $\mathrm{CuCC}$ nouns are contrastive. $\mathrm{CuCuC}$ nouns are frequently used for plural nouns whose singular has a $\mathrm{CvC} \overline{\mathrm{v} C}$ shape, e.g. kitāb pl. kutub 'book' and rasūl pl. rusul 'messenger' (Ratcliffe 1998, 105) whereas the plural of elatives and adjectives of colour and bodily defects have a plural pattern CuCC, for example ?akbar pl. kubr 'greater' and Pahmar pl. humr 'red'. Minimal pairs such as h.umur (sg. himār) 'donkeys' versus h.umr (m.sg. Pahmar) 'red (pl.)' suggest that we are dealing with a genuine contrast. ${ }^{16}$

The possibility of the existence of $\mathrm{CuCuC}$ nouns besides $\mathrm{CuCC}$ nouns, even within a single dialect would allow to explain why specifically nouns of this shape seem to yield conflicting results in terms of the syllable structure reflect in the rhyme. Therefore it seems that Fox $(2013,150)$ is correct to say that not all $\mathrm{CuCuC} \sim \mathrm{CuCC}$ alternation can be explained as the result of epenthesis and syncope, and that, for reasons that are not entirely clear anymore, some forms of Arabic, including Quranic Arabic, had the freedom to use $\mathrm{CuCuC}$ and $\mathrm{CuCC}$ shapes side by side.

16 One might cast doubt on this contrast as it appears in a literary language, and could be envisioned to be an invention of the grammarians to form a contrast between the two. While in quite a few dialects the two patterns do merge (either towards $\mathrm{CuCuC}$ or towards CuCC), at least in Cairene Arabic the contrast appears to be maintained, e.g. kitāb pl. kutub but ?ațraš pl. țurš 'deaf'. 


\subsection{Development of the Phoneme $\bar{e}$}

Rabin (1951, 16o, §v) points out that a distinction between ?alif maqșūrah when the root is III- $y$ and III- $w$ both in verbs and in nouns is clearly present in the rhyme and spelling of the QCT (see also Nöldeke et al. 2013, 415; van Putten 2017a). Thus, we find هدى / دعا /hadē/17 'he guided' (Q2:143) versus 'he called' (Q3:38), and الهدى /al-hudē/ 'guidance' (Q3:73) versus سناى /sanā/ 'flash' (Q24:43). While Rabin takes the form hade etc. as analogical innovations from *hadā, it is now clear from Pre-Islamic Arabic and comparative evidence that the vowels $\bar{e}$ and $\bar{a}$ have distinct etymological origins, where $\bar{e}$ develops from *ayV, whereas $\bar{a}$ either descends from original ${ }^{*} \bar{a}$ or from ${ }^{*} a w V$ (van Putten 2017a).

Al-Farrā? (Lug் $\bar{a} t$, 21f.) explicitly states that the people of the Hijaz merge the III $-y$ and III- $w$ verbs towards $\bar{a}$, whereas the people of Najd have $\bar{e}$ for III $-y$ verbs and $\bar{a}$ for III- $w$ verbs. He adds that it is best to pronounce the vowel in between "extreme $i$ " (al-kasr al-šadìd) and "extreme $a$ " (al-fath al-šadìd) and that the majority of Arabs and readers follow that practice. This comment is surprising on several levels. First, al-Farrā? seems to explicitly endorse making a distinction between the two long vowels, different from what becomes the standard in Classical Arabic which merges the two towards $\bar{a}$, and second that it is certainly not the majority of readers or Arabs who make this distinction today. This latter comment should probably be understood from the Kufan context from which al-Farrā? writes. The Kufan readers Ḥamzah, al-Kisā?ī and Xalaf all read the III$y$ with /ēel. Warš Yan Nāfí also makes this distinction consistently, pronouncing the III- $y$ with / $\bar{a} /$. The rest of the readers of the 10 all regularly merge the sounds (with the exception of ?abu Yamr at the end of a verse, see §3.6.6.1). The comment that the 'majority of the Arabs' apparently had a phonemic distinction between /ä/ (if in between extreme $i$ and extreme $a$ does not just point to /ē/)

17 Rabin takes this final $\bar{e}$ to have been phonetically a diphthong [ay]. The spelling in the QCT does not allow us to distinguish the monophthongal value [ēe from [ay], but I take the monophthongal pronunciation in the readings of Ḥamzah and al-Kisā?î to be significant here. I am not convinced by Owens' $(2006,199)$ argument for seeing Pimālah as a rising diphthong [iə] or [ia]. This analysis is primarily based on the idea that Pimālah is spelled with a kasrah in front of the ?alif by Sībawayh and that other authors such as Ibn Muǧāhid even describe Pimālah, for example in a word like têeba as having "kasr al-țā?". This analysis (although by no means certain) might work in front of Pimālized ās that are written ?alif, but breaks down in words like hadè spelled هدى, by Owens' logic these words should be pronounced **hadī. Indeed, such cases of Pimálah are explicitly described in the same terms, e.g. Al-Farrā? (lughāt, 21): wa-kațīrun min Pahli nağdin yaksirūna, fa-yaqūlūna, قضى

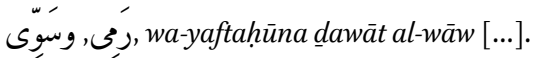


and /ā/ does highlight that whatever 'Arabic' was at the time of al-Farrā?, was clearly distinct from textbook Classical Arabic.

If al-Farrā? is correct in attributing the $\bar{e} / \bar{a}$ contrast of this feature to the Najd, then this would mean we have a phonetic feature of Quranic Arabic that is proper to Najdi Arabic rather than to the Hijaz. If this feature was ever part of Hijazi Arabic, it seems that at the time that Sïbawayh and al-Farrā? were active, this distinction had clearly fallen out of use in the Hijaz, some 150 years after the codification of the Quranic text. There are perhaps a few remaining memories of the feature in the Hijaz to be discovered in Sỉbawayh's Kitāb. Rabin points to the passage in Sibawayh (IV, 256) where he tells us that "some Arabs say șawaray, qahalay and dafaway, so they make it (the ?alif maqșūrah) a $y \bar{a}$ ?, and they are like those they agree with those who say Paffay, and these are people from Qays and the people of the Hijaz". This appears to be a reference to Sibawayh (III, 414) where he says that "some Arabs say ?affay, with the hiding of the ?alif in pause; and if it is pronounced in context, it is not done. And from them there are some that say ?affay in pause and in context, so they make a $y \bar{a}$ ? follow it." All of these statements exclusively pertain to the feminine ending $-\bar{e}$, it is difficult to decide how we should understand this with stem-internal forms such as al-hude and banē.

More salient evidence that a shift of the treatment of $\bar{e}$ towards $\bar{a}$ was under way in the early Islamic period can be found in early transcriptions and developing orthography in papyri and inscriptions of this period. Graeco-Arabic transcriptions of the first century show that $\bar{e}$ was still distinct among the conquerors of Egypt in the first Islamic century, e.g. $\mu \alpha \nu \lambda \varepsilon$ /mawlē/ 'client', เ $\alpha \varepsilon \varepsilon \varepsilon$ /yahyēe/ 'Yahyāā (personal name)', $\alpha \lambda \varepsilon$ /yạlē/ 'YaSlā (personal name)' (Al-Jallad $2017 \mathrm{~d}, 431$ ). By the time that the Damascus Psalm Fragment was written, which may be as early as the 8th century, the contrast that was present in the first Islamic century has disappeared (Al-Jallad 2020b, $47 \mathrm{f}$.).

In Arabic papyri and inscriptions, we find evidence for such a shift as well. One of the typical features of Quranic orthography is that the $\bar{e}$ is written with $y \bar{a}$ ? in all contexts. While Classical Arabic orthography continues to distinguish III- $y$ and III-w in word-final position, e.g. هدى $h a d \bar{a}$ and $d a \oint \bar{a}$, the contrast is neutralized before pronominal suffixes, e.g. هداه hadā-hu and دعاه da dā-hu. In Quranic orthography however, such suffixed forms are not written with an ?alif but are written with a $y \bar{a} ?$ just like in final position, i.e. هديه, clearly suggesting the vowel was not yet homophonous to the ?alif.

Finding spellings of either type in the early Islamic period is difficult, but the Mufāwiyah dam inscriptions from 58AH has the Quranic style of spelling: 'he built it', instead of *** بن (Miles 1948). By the time the formulation benediction $? a b q \bar{a}-k a / h u$ !ḷăh 'may God preserve you/him' becomes popular in papyri 
the eighth century, the Classical spelling is the only one attested, e.g. العاه الله (CPR XXI $5,1.3 ; 182 \mathrm{AH}) .{ }^{18}$ If we assume the inscriptions and papyri to be direct continuations of the language of the Quran, this data could be interpreted as showing a diachronic development of Quranic/Hijazi Arabic from a situation that distinguishes $\bar{e}$ and $\bar{a}$ to one that has merged the two sounds. The eastern dialects would then appear to have held off this merger for a longer time, and thus make it into the descriptions of the grammarians. ${ }^{19}$ The fact that the Arab grammarians consider this $\bar{e}$ purely a by-form of the ?alif-even though it is a separate phoneme - also suggests that the base language the grammarians are arguing from is a dialect that has merged these forms.

From a pre-islamic epigraphic perspective we can see some interesting developments that, however, do not help much towards solving this conundrum. In Safaitic the historical triphthongs are still actual triphthongs, i.e. *aya and *awa (Al-Jallad 2015, 47), e.g. ' $w$ [Galawa] 'to ascend'. However III-w often merges towards III- $y$, e.g. $n g w$ [nagawa], $n g y$ [nagaya] 'to escape' (Al-Jallad and Jaworska 2019). In Hismaic, the *awa seems to have collapsed towards $\bar{a}$, while the *aya was still distinct, i.e. $d^{\prime}$ [da؟ā] 'he called' but bny [banay(a)] 'he built' (Al-Jallad 2020a). For Nabataean Arabic, the sounds appear to have collapsed to $\bar{a}$, as final *ayV sequences are spelled with aleph: אלעזא /al-Yozzā/ 'al-'Uzzā' (Cantineau 1978, 128) and דושרא / The QCT in having the ê/ā contrast is thus archaic (and more archaic than Nabataean Arabic) and not innovative in this regard.

\subsection{Hollow Root Pimālah}

Where Quranic Arabic appears to have retained a distinction between wordfinal triphthongs with III- $w$ and III- $y$, the triphthong in hollow roots has quite clearly collapsed to $\bar{a}$. These are still distinct triphthongs in the Old Arabic reflected in most Safaitic inscriptions (Al-Jallad 2015, 47), and al-Farrā? (Lugiàt, 17) indeed confirms what the QCT suggests (see $\S 2.2 .2 .3$ ): The people of the Hijaz pronounced with a pure $\bar{a}$ regardless of whether the second root consonant was $w$ or $y$. But the common people of the Najd, among the Tamim, ?asad and Qays would apply Pimālah to the II-y roots such as šể?a, ğêe?a, xêfa, têeba, $k \bar{e} d a$ and $z \bar{e} \dot{g} a$.

18 This papyrus has been accessed through the Arabic Papyrology Database (https://www .apd.gwi.uni-muenchen.de/apd/project.jsp)

19 Although even there not unscathed, the descriptions of Sībawayh and al-Farrā? are irreconcilable, which suggests even there a merger may have been under way $(\S 3 \cdot 3 \cdot 3 \cdot 3)$. 
Rabin (1951, 111-113) sees this quote (which he gets indirectly from Ibn YaGǐš) as a contradiction with what Sībawayh says. As Sībawayh (IV, 120) says that it is a linguistic practice among some of the people of the Hijaz (wa-hiya lugatun li-baSḍi Pahli l-hiğāzz). Thus, he suggests that Ibn YaYišs mistakenly reversed the attribution of this type of Pimālah to the Najdi tribes. Now that we no longer need to rely on the indirect quote of Ibn YaSišs (Šarh al-Mufașșal, v, 188), but have access to the quote of al-Farrā? directly, it is now confirmed that Ibn YaGī̌s was quoting al-Farrā? correctly, despite the apparent contradiction with Sībawayh.

However, one wonders whether this should be understood as a contradiction between the two authors, rather than a lack of specificity of Sỉbawayh. Sïbawayh (IV, 12O f.) attributes the collapse of the medial triphthong to $\bar{e}$ to be "a linguistic practice among some of the people of the Hijaz; but the general populace does not apply Pimālah." He makes no mention of whether this is practiced outside of the Hijaz. This interpretation would seem to resolve the apparent contradiction between the report of al-Farrā? and Sïbawayh. The fact that it is explicitly mentioned to be a marginal feature in the Hijaz means that we should not find it particularly surprising that the feature is absent in the QCT.

\subsection{Major Assimilation in Gt-stems.}

Another case where a feature that we find in the Quran does not get attributed to the Hijaz is the occasional assimilation of coronal consonants across vowel boundaries. Al-Farrā? (Luġāt, 27) reports that many of Qays and Tamīm say muhaddūna or muhuddūna for muhtadūna whereas the people of the Hijaz avoid such assimilations.

There are three places in the Quran where the QCT could be understood as having undergone such an assimilation. First is Q10:35 يه which is variously read as, yahaddī, yahădd $\bar{\imath}$, yahiddī, yahddī, yihiddī and yahdī (Ibn alĞazarī, §3256), second Q36:49 يخصمون which is variously read as yaxașsimūna, yaxășșimūna, yaxișșimūna, yaxșșimūna and yaxșimūna (Ibn al-Ğazarī, § 4010)

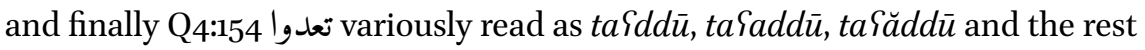
$\operatorname{ta} \hat{\Upsilon} d \bar{u}$. These three verbs also occur unassimilated elsewhere in the Quran (e.g. Q10:108; Q3:44; Q2:231). Whether we are really dealing with assimilated forms of this type, however, depends on the trust one places in the majority of the readers to properly reflect the language of the QCT, and how much trust one places in the linguistic facts as presented by al-Farrā?

On discussing the form Q10:35 1 , al-Farrā? (Luġāt, 72) tell us that among the people of the Hijaz hadā 'to lead' may have the same meaning as ihtadā 'to 
be rightly guided' and that the readers used to recite this verse as ?am-man yahdī Pillā ?an yuhdā using that meaning thus: "or he who is rightly guided only if he is guided (himself)" rather than the straightforward understanding of this reading with yahdi "or he who guides only if he is guided (himself)." If we accept al-Farrā?'s report that hadā may have the meaning of ihtadā in the dialect of the Hijaz, then we are not clearly dealing with the QCT reflecting a non-Hijazi form, as this verse may have been read as yahdi, lacking the non-Hijazi assimilation. However, there is some reason to doubt this account. Al-Farrā?'s teacher al-Kisā?ī and his teacher Ḥamzah are the only canonical readers that read yahdī. Al-Farrā?'s comment may be a fabrication to simultaneously defend the semantics of the majority reading and the pronunciation of his fellow Kufans. We do find examples where G- and Gt-stems of the same root have (more or less) the same meaning, this tends to happen when the Gt-stem has a medial transitive, not passive meaning, and therefore has a meaning close to the transitive G-stem, e.g. šarā- $h u$ 'he bought it' and ištarā-hu 'he bought it (for himself)'. In the case of hadā in the meaning of ihtadā, however, we are not dealing with a medial transitive meaning of the Gt-stem but a passive meaning of the G-stem. I know of no example where the G-stem can have a passive meaning where the Gt-stem does too.

Q36:49 يخصمون yields less obvious semantic problems. Both xasama and ixtașama may have more or less the same meaning "to quarrel", although the former also has a transitive meaning "to quarrel with someone". Al-Farrā? (Lug $\bar{a} t, 120)$ comments on the different outcomes of the assimilation of the ixtașama reading, but makes no special comment on the semantic of Hamzah's reading yaxșimüna. He gives a more in-depth discussion of the meaning of this reading in his Maৎānīal-Quriān (Al-Farrā? Maৎānī, II, 379).

Q4:154 انعدوا likewise yields few semantic problems. Both $\{a d \bar{a}$ and $i$ Stadā can have the meaning "to transgress". Al-Farrā? does not discuss this variant, presumably because in this case the G-stem interpretation is the majority reading (and the reading of the Kufans he was most intimately familiar with).

If we take these forms as assimilated, then they are the only cases of $\mathrm{Gt}$ forms in the QCT with an assimilation that al-Farrā? attributes to Tamim and Qays. In all other cases the QCT explicitly agrees with the Hijazi form. However, throughout the Quran, not infrequently, we find examples of assimilation of especially coronal consonants or identical consonants across vowels. This is especially commonly attested with tD- and tL-stems, such as fa-tațahharu $\rightarrow$ ف فاطهرو $f a$ țahharū (Q5:6). It also occurs in cases where two consonants assimilating are identical, examples in the QCT are: اتحجونى Pa-tuhăğğğūn-ni 'do you argue with me?' (Q6:80), تامرونى ta?murūn-nī, tāmurūn-nī, ta?murūn-niya, tāmurūn-niya 
'you ordered me' (Q39:64), تامنا taiman'w-nā, tāman ${ }^{w}-n \bar{a}$, tāman-nā 'you trust us' (Q12:11) فنعما, نعما 'makkan-nī 'has established me' (Q18:95), فكنى

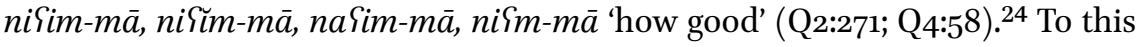
we may also add the rare contraction of geminated apocopates that we discussed in $\S 4.9$ above.

It seems then that this kind of assimilation across vowels was somewhat productive in Quranic Arabic. Such forms do not usually get attributed to specific dialects of Arabic at all, and seem to be quite particular to Quranic Arabic.

\subsection{1 * ra?aya, *na?aya > rā?a, nā?a}

Another feature suggested by Rabin (1951, 142 f., § ii) to be a Hijazi development is the apparent metathesis of original II-P III- $y$ verbs to II- $y$ III-P, thus original "ra?aya 'to see' and "na?aya 'to move away' shift to rā?a and nā? $a$ rather than

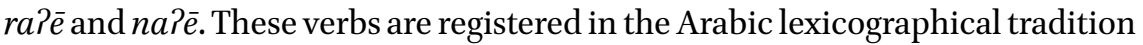
(Lane 1197b; Lisān 459oc), and it is quite clear that their spelling in the QCT as ا (e.g. Q6:76, 77, 78) and (Q17:83; Q41:51) should be understood as reflecting such forms (as also recognized by Rabin). While none of the canonical readers read $r a \bar{a} / \bar{e}$ as $r \bar{a} P a$ - despite the rasm-Ibn Dakwān Yan Ibn Yāmir and Pabū Ğaffar both read na?āa/e as nā̃a (Ibn al-Ǧazarī, §3478).

The suggestions that this form is Hijazi is confirmed by al-Farrā? (Lujāt, 8 of.) who comments on these words. He claims that both $n a \bar{a} \bar{a}$ and $r a ? \bar{a}$ are the Qurashi form and he adds that this is how one recites the Quran (he is seemingly unaware of Ibn Sāmir and Pabū ĞaSfar's reading). He follows this up by a list of mostly Hijazi tribes that do have $n \bar{a} ? a$ and $r \bar{a} \bar{\imath} a$ however: for Hawāzin among its branch of the SaSd b. Bakr, the Banū Kinānah, Hudayl and many of the Medinans (specifically the Panșār). He adds that in the fa Saltu form this metathesis does not take place and they say ra?aytu and na?aytu. This is indeed in line with what we see in the QCT where suffixed forms of rāpa 'to see' are usually spelled رايت and occasionally ريت in early Quranic manuscripts, pointing to /rāyt/ or/ra?ayt/. All the tribes and people mentioned

\footnotetext{
21 Also read as ta?murū-niya, tāmurū-niya (Ibn al-Ǧazarī, 4091). Ibn Yāmir reads ta?murūna$n \bar{\imath}$, following the Syrian rasm تامرونى (Sidky 2021).

22 Almost universally read with labialization of the first $n$, but Pabū Ğaffar reads tāman-nā (Ibn al-Ǧazarī, §3326).

23 Also read as makkana-nī by Ibn Katīir (Ibn al-Ǧazarī, § 1208). This is also reported as a rasm variant for the Meccan rasm (Sidky 2021).

24 Ibn al-Ǧazarī, §2806.
} 
are situated in or around the Hijaz, and thus this feature is clearly Hijazi, although strikingly explicitly denied to be Qurashi.

\subsection{Lexical Isoglosses}

Besides some of the generalizable phonological details as discussed on the sections above, al-Farrā? in his Luġāt al-Quriān lists many isoglosses of specific lexical items, which represent certain differences in vocalization or metathesis. These cannot always be confidently be seen as the result of a regular sound law, and some certainly reflect the outcome of some irregular shift. Nevertheless, such forms can be compared against the QCT, to see to what extent they support a dialectal identification. Whenever the QCT allows us to distinguish such lexical isoglosses, it invariably points towards the Hijazi form.

This is significant, as this is not at all what we find among the reading traditions when the QCT is ambiguous. Even in such cases the readings quite often agree with the form attributed to the Hijaz, but far from always. In other words, the Quranic readers did not feel forced to stick to what was believed to be the Hijazi/Qurashi forms (see § 3.4). But when the rasm leaves no other choice, the readers fall in line, and as a result end up having the Hijazi form. This is strong evidence of the Hijazi character of the QCT. The following list gives examples of forms cited by al-Farrā? (Lugāât). After each option the tribal attribution is given in brackets, followed by the page number where the isogloss is discussed. Finally, the QCT form is listed. While it is not possible to define more specific sound laws for these isoglosses, I have categorized them into several general types.

\section{Metatheses}

- șā Siqah pl. șawā Yiq 'thunderclap' (Qurayš and those eloquent Arabs around them), șāqiSah pl. șawā Siq (Tamīm, Rabīiah), p.16. QCT: Qurayš الصعقه (Q2:55 etc.) pl. الصوعق (Q2:19; Q13:13).

- Samīq 'deep’ (Hijaz), maৎ̄q (Tamīm), p. 99. QCT: Hijazi عميق (Q22:27).

- Satā 'to act wickedly' (Hijaz), §āta (Tamīm, Qays and Pasad), p. 25. QCT: Hijazi تعثوا (Q2:6o).

- hāǎsa 'to shun, forbid' (Hijaz), ḥāšā or ḥašāa (others), p. 83. QCT: Hijazi $(\mathrm{Q} 12: 31) \cdot{ }^{25}$

25 It is worth noting here that Pabū Yamr ignores the rasm and reads ḥā̌sa (Ibn al-Ğazarī §3335). 


\section{Alternations with semi-vowels or long vowels}

- qinwān 'cluster of dates' (Hijaz), qunwān (Qays), qinyān (Kalb), qunyān (Tamim, Dabbah), p. 62. QCT: Hijaz or Qays: قنوان (Q6:99).

- qușwā (Hijaz), ${ }^{26}$ qusyā (widespread practice [al-luġahal-făšiyah]), p. 71. QCT: Hijazi القصوى (Q8:42). The merging of III-w and III-y roots towards III-y in this formation is well-attested elsewhere, e.g. QCT العليا (Q9:40) and الدنيا (passim).

- Padāan 'announcement' (common speech among the people of the Hijaz, and Najd), Padinn (Some of the Qays), p. 72. QCT: non-Qays اذن (Q9:3).

\section{Hamzahs}

- tawkid 'affirmation' (Hijaz), ta?kid (other Arabs), p. 79. QCT: Hijazi توكيدها its confirmation' (Q16:91). This form is likely the result of the reanalysis of the $\mathrm{I}-\mathrm{P}$ verb as a I-w verb, due to its use in the D-stem leading to a partial merger. See $§ 6.4 .2$ for a discussion.

- wașid 'entrance' (Hijaz), Pașīd (Najd), p. 86. QCT: Hijazi بالوصيد (Q18:18).

- daiama 'to blame' (Hijaz), d̦āma ( $\underline{\text { d } y m) ~(Y u d r a h, ~ Q a y n, ~ m a n y ~ o f ~ Q u d ̣ a ̄ Y a h), ~}$ p. 64. ${ }^{27}$ QCT passive participle مذوما (Q7:18) 'disgraced' is not consistent with II- $y$ where madim is expected (see also $§$ 4.16.2).

\section{Irregular consonantal correspondences}

- ladun 'near, close' (Hijaz), ladu (Tamim), p. 49. Qст: Hijazi لدن (Q27:6).

- quțr pl. Paqțār 'region' (Hijaz), qutr pl. Paqtār (Qays), p. 117 f. QCT: Hijazi اقطارها (Q33:14).

- ğadat pl. Pağdāt 'great' (Hijaz), ğadaf (Tamīm), p. 98. QCT: Hijazi الاجداث (Q36:51).

- Pağāâa 'to bring' (Hijaz) Pašāâa (Tamīm), ${ }^{28}$ p. 89. QCT: Hijazi فاجاها 'So he brought her' (Q19:23).

26 In fact, also the masculine elative retains a trace of the root final consonant " $w$, as it is spelled اقصا / /aqșā/ with the regular outcome of Proto-Arabic *?aqșawu, rather than ***âșē/ (van Putten 2017a, 6o). This is not commented on by the Arab grammarians, as they do not distinguish between the two etymologically distinct Palif maqșürahs.

27 One might wonder how to understand this statement of al-Farrā? in light of the fact that hamzah has been lost in the Quran. But II-? verbs remain distinct from II-w/y verbs morphologically, even though it is likely the $a$ ? a sequence had shifted to $\bar{a}$, e.g. sa?alta $>$ /sālta/ but, e.g. kunta $>/$ kunt/.

28 One wonders whether this description of the Tamīmī form is intended to designate the voiced post-alveolar fricative pronunciation of the ğim as is common in many Levantine Arabic dialects today. But there is no way to be certain. 
- qāa 'a distance’ (Hijaz), qìd (Najd), qidā (some of Ġațafān), p.134. QCT: Hijazi قاب (Q53:9).

- xasafa 'to darken' (Hijaz), kašafa (Tamīm, Qays, ?asad), p. 149. Qст: Hijazi خسف (Q75:8).

- kušițat (Qurayš); qušițat (Qays, Tamīm, Pasad) p.153. The QCT: Qurayš كشطت (Q81:11).

As this list illustrates, the QCT invariably has the Hijazi or Qurashi form. In AlFarrā?'s list I have identified one case where the QCT gives a mixed answer and both reported dialectal forms are attested. One must keep in mind in this case that al-Farrā?'s wording is seldomly explicitly exclusive. Just because a certain form occurs in the Hijaz, while another form occurs elsewhere need not mean that one or the other did not have both. The example I have found is the following:

- Pamalla 'to dictate' (Hijaz, Pasad), Pamlā (Tamīm, Qays), p. 41. As al-Farrā? points out, the QCT has both: تملى 'they are dictated' (Q25:5), ويملى 'so let him dictate' (Q2:282). ${ }^{29}$

There is one more example where the QCT seems to have both forms reported. Hijazis treat tág $\bar{a}$ 'to overflow' as a III- $w$ verb, while some of the Tamìm treat it as a III-y verb (al-Farrā? Lug $\bar{a} t, 143$ ). The QCT has both forms, but seemingly with a semantic distinction. طغى/țagè / 'he transgressed' (Q20:24, 43; Q53:17; Q79:17, 37) and طغ /țaḡā/ 'it overflowed' (Q69:11). Van Putten (2017a, 6of.) argues that the meaning 'to overflow' is the original inherited word, whereas 'to transgress' is borrowed from Aramaic, with its treatment as a III- $y$ verbs borrowed along with it. While these two verbs are often taken to be the same verb (e.g. Diem 1979, 239), and thus the spelling with ?alif as evidence that the two ?alif maqșūrahs denote the same sound, it seems that this may not have been the case for al-Farrā?. Al-Farrā? usually cites dialectal variants at their first appearance in the Quran in his Lugät al-Qur?ān, but the discussion of

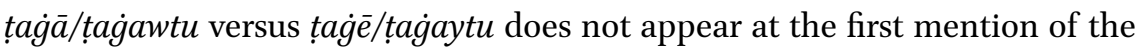
verb tage spelled طغ طن at Q20:24, but instead at the first and only mention of its spelling as (Q69:11) where it means 'to overflow'. This may perhaps be taken as an indication that al-Farrā? indeed considered these two verbs to be different, and mentions here that they may merge in Tamīmì.

For these lexical isoglosses, it should be clear that whenever the QCT allows us to identify the dialectal form of the text it consistently sides with Hijazi Arabic. The only exception I have found attests both the Hijazi and the non-Hijazi dialectal form.

29 Interestingly, al-Farrā? also cites واملى لمم/wa-Pumlī la-hum/ (Q68:45), now generally understood with the other meaning of the verb ?amlā as 'And I will give them reprieve'. 


\subsection{Phonetic Isoglosses Not Recognized by the Grammarians}

There are several phonetic isoglosses in Quranic Arabic that from a comparative perspective clearly set Quranic Arabic apart from Proto-Arabic in its ancestral stage, but whose features either are not recognized at al by the grammarians, or do not receive an explicit dialectal identification.

\subsubsection{Stative II=III Are zalla/zaltu or ziltu}

While Classical Arabic generally breaks up geminated stative verbs like zalla/ zalittu in the suffixed forms, the QCT treats these verbs differently from zanna/zanantu, and has a biliteral form فلت (Q20:97), فظلت (Q56:65). Rabin $(1951,163$, §aa) suggests that this might be a specifically Hijazi innovation but this does not seem to be corroborated by the two early grammarians we examine here. Sibawayh (IV, 421) discusses such forms but just discusses it in 'their speech' as opposed to zaliltu forms which he says is 'your speech'. Al-Farrā? (Luga ät, 93) does not seem to consider the zaliltu form at all (though see alFarrā? Maৎānī, II, 19o). He says zalta is the speech of the Arabs, and some of the Tamim say zilta. The presence of this feature of the QCT does not seem to have been considered specifically Hijazi.

\subsubsection{Pausal Shortening of Final $-\overline{1}$}

Rabin (1951, 119, §ii) notices that the 1sg suffixes $-n \bar{\imath}$ and $-\bar{\iota}$ often appear shortened in the QCT. In fact, this overwhelmingly occurs in pause (see van Putten and Stokes 2018, 156-158), but appears to have been optionally available outside of pause as well. Moreover, it does not just affect these suffixes but every single case of word-final $-\bar{\imath}$ in the QCT. This feature is suggested by Rabin, and likewise by Blau $(1977,15)$ and Nöldeke $(1910,4)$ to be a colloquialism of the Meccan dialect. All authors appear to be under the assumption that this feature is not part of the Sarabiyyah, but this is not backed up by the comments of the grammarians - nor are such forms explicitly attributed to the Hijaz by them.

Sïbawayh (IV, 183) reports that indefinite III-y nouns of the type qădin and $\dot{g} \bar{a} z i n$ are normally pronounced $q \bar{a} d, \dot{g} \bar{a} z$ in pause, although "some Arabs whose Arabic is to be trusted" say rāmi , $\dot{g} \bar{a} z \bar{l}$. But some among the Arabs (no dialect given) are said to shorten the forms in pause, even for the definite form, thus $a l-q \bar{a} \underline{d}$ in pause for al-qād $\bar{\imath}$. No specific example is given, but this is exactly the

The fact that al-Farrā? cites it here, suggests he understood this verse to mean 'And I will dictate for them.' 
type of distribution that we find in the Quran, thus الزانى 'the adulterer' (Q24:2) in context, but بالواد 'the wadi' (Q89:9) in pause.

For the verb, Sībawayh (IV, 184f.) considers this an anomalous practice (ša $\underline{a} \underline{d} \underline{d}$ ), but does say it occurs, thus you get forms like lā Padr for 'I do not know', and he specifically says it is more fit (?ağdar) to do this with nouns (citing the Quran), but points out that it occurs for verbs at the ends of phrases in the Quran ( fawāṣil) citing wa-l-layl Tida âyasr\# 'by the night when it passes' (Q89:4) and $m \bar{a}$ kunnā nabj\# 'what we have been seeking' (Q18:64). ${ }^{30}$

For the 1sg. suffixes Sibawayh (IV, 185 f.) considers the shortening to be the more regular and more common practice in pause, citing forms such as $h \bar{a} \underline{d} \bar{a}$ gulām-ø\# 'this is my slave boy', wa-qad ?asqā-n\# 'he has given me to drink'. For these pausal shortenings of $-\bar{l}$, Sïbawayh cites no regional preferences and cites a variety of Quranic verses and lines of poetry.

Al-Farrā? (MaYānī, I, 9o) discusses the phenomenon of shortening final $-n \bar{\imath}$ and $-\bar{i}$ to $-n i$ and $-i$ respectively, and says that both the retention of length and the shortening is correct. He does not connect it with pausal pronunciation, presumably because in the Quran it occurs not infrequently outside of pause as well. He adds that it is common to shorten these forms, but does not consider it specific to the Hijaz or to any eastern tribe, but as a general phenomenon.

So, while this isogloss is certainly part of Quranic Arabic, there does not seem to be compelling external evidence to connect this feature with the Hijaz. Its identification as Hijazi is therefore purely based on its appearance in the QCT, this is, of course circular when investigating the linguistic character of the Quran.

\subsubsection{Word-Final $\bar{a} y / w>\bar{a}$ ?}

In word-final position, the sequence * ${ }^{*} y$ (and probably also * ${ }^{*} w$ ) has shifted to $\bar{a}$ ? in Quranic Arabic. Rhyme suggests that this was one of the few places where Quranic Arabic retained a reflex of the hamzah (van Putten 2018, 103 ff.). Comparative evidence with Safaitic shows that this variety of Northern Old Arabic

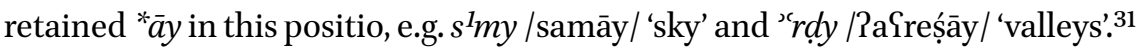

It has been suggested by Rabin (1951, 141, §ee) that one of the dialectal isoglosses between Hijazi Arabic and Najdi Arabic is that Hijazi Arabic has $-\bar{a} ?$

$30 \quad$ Note that apparently to Sībawayh fāṣilah does not just mean 'end a verse in the Quran', but even 'end of a phrase in the Quran', as mā kunnā nabj( $i)$ is not a verse ending in any regional verse count (Spitaler 1935, 43; al-Dānī 1994, 189).

31 Some dialects in Yemen, like Safaitic, but unlike Quranic Arabic never underwent this development, and still have $-\bar{a} y$ in, e.g. samāy (Behnstedt 1987, $59 \mathrm{ff}$.). This is not likely to be an otherwise unmotivated shift from ${ }^{*}$ ? $>y$, as Behnstedt assumed. 
(i.e. Palif mamdūdah) as an outcome of ${ }^{*} \bar{a} y$, whereas Najdi Arabic has $-\bar{a} / \bar{e}($ i.e. Palif maqșürah). This isogloss works well for the plural demonstrative which in

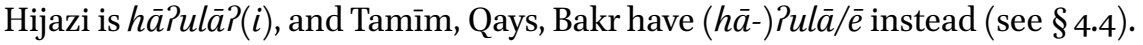
But, the evidence of the early grammarians does not give very strong evidence that Hijazi $-\bar{a}$ ? versus Najdi $-\bar{a} / \bar{e}$ to words other than the demonstrative, however. Al-Farrā? (Luġāt, $18 \mathrm{ff}$.) reports that the Qurayš and those that surround them, and the people of Najd lengthen nouns of the type bināian, whereas some Arabs shortened it (i.e. binan). He adds that some of Qays say Pinšāyan and bināyan, retaining (at least in this context) the original " $y$ consonant. He adds that he does not approve of shortening forms like binā?an and mā?an to binan and man "because it mixes up the lengthened (i.e. nouns that end in $-\bar{a}$ ?) and the shortened (i.e. nouns that ends in $-\bar{a} / a n)$."

He also discusses انيه Pinā-hu, Pinē-hu 'the extent of it' (Q33:53), mentioning that it is a widespread Quraši practice, while (other) people of the Hijaz, Najd and Hudayl say ?iny whereas some Arabs says ?anā? instead. Here the ?alifmaqșürah form is specifically connected with the Qurayš, but the lengthened form not with any specific tribe (al-Farrā? Lug āt, 117).

For بسيمهم 'by their mark' al-Farrā? (Luġāt, 41) reports for bi-simā-hum for the Quraysh while 'another practice' is bi-simā?i-him and that Taqif and some of al-?asd (= al-Pazd?) say bi-simyā̄i-him.

There can be no doubt that the language of the QCT retained a distinction between the Palif mamdüdah and Palif maqșürah, yet the evidence in favour of a geographical split remains sparse, and conflicting.

\subsubsection{Pharyngealization of the Emphatics}

In the pre-Islamic Graeco-Arabica of the southern Levant, presumably reflective of the local dialect of Nabataean Arabic, the emphatic consonants $d$ and $z$ are represented with $\sigma$ and $\tau$ respectively. These transcriptions certainly point to unvoiced realizations, which suggests that they may have still been ejectives (which cannot be voiced). Moreover, the lack of any effect of the emphatic consonants on the surrounding vowels, seems to further corroborate that they are ejectives rather than pharyngealized consonants (Al-Jallad 2017a, 128).

While it is not possible to tell from the QCT whether these emphatic consonants were voiced or not, it is clear from the spreading effect that the emphatic consonants have on surrounding consonants that they were pharyngealized, as ejectives are typically non-spreading (van Putten 2019b). This is a specific development of Quranic Arabic as opposed to the northern dialects, and gets described for Arabic more generally by the Arab grammarians. No specific mention seems to be made of ejective realizations, which may have largely fallen out of use by the time the Arab grammarians were active. 


\subsection{The Quran Is Phonologically Hijazi}

As with the morphological features of Quranic Arabic, the phonetic features likewise give a clear picture: Whenever the QCT allows us to examine the phonetic features of the language of the Quran, it quite consistently points in the direction of the Hijaz. Only occasionally the data of the Arab grammarians does not agree with the attested data, most notably with the treatment of the word-final /ē/. In this case, a plausible case can be made that Quranic Arabic is archaic in this regard and the descriptions of the grammarians might simply be an inaccurate reflection of early first century AH Arabic because by the late second century Hijazi Arabic had lost this phoneme. The table below once again lists the features found in the Quran and to which tribe they have been attributed by the grammarians. Likewise, it is shown which innovations can be shown to have not taken place in Northern Old Arabic. Once again, we find that the QCT overwhelmingly points to the Hijaz in terms of its phonetic features, and that many of those features are absent in Northern Old Arabic varieties.

\begin{tabular}{|c|c|c|}
\hline & Grammarians & $\begin{array}{l}\text { Northern Old } \\
\text { Arabic }\end{array}$ \\
\hline Loss of the glottal stop & Hijaz & Absent \\
\hline The Phoneme $\bar{o}$ & Hijaz & $?$ \\
\hline Lack of Cȳ̄ > Cī & Hijaz & $?$ \\
\hline Passive hollow roots $\mathrm{CīCa}$ & Hijaz & Absent \\
\hline Retention of șirāt & Hijaz & $?$ \\
\hline No syncope of $\mathrm{CvCu} / \mathrm{iC}>\mathrm{CvCC}$ & Hijaz & $?$ \\
\hline III-y $-\bar{e}$ distinct from III-W $-\bar{a}$ & Najd & Absent \\
\hline Major Assimilation of Gt-stems & Hijaz, perhaps two words Najdi & Absent \\
\hline Absence of Hollow root Pimālah & Hijaz & $?$ \\
\hline${ }^{*}$ Ca?aya $>$ Cā?a & Hijaz (but not Qurayš) & Absent \\
\hline Lexically specific isoglosses & Hijaz & $?$ \\
\hline${ }^{*} \bar{a} y>\bar{a} ?$ & General Sarabiyyah & Absent \\
\hline Pharyngealization of emphatics & General Sarabiyyah & Absent \\
\hline
\end{tabular}


In this and the previous chapter we have examined the morphological and phonological isoglosses of the language of the Quran, not as it is presented by the - often conflicting - reading traditions, but as it is reflected by the only part of the text that certainly existed in the very beginning of the Islamic period, the Quranic Consonantal Text.

Very different from the view we get if we would take any one of the reading traditions, a very consistent picture emerges: All its features align with what the early Arab grammarians identify as Hijazi Arabic. I believe that this evidence should be taken seriously. There is no positive evidence at all that the Quran was composed in an intertribal poetic koiné whose features remain undefined by those that have advocated such a position. Instead, it seems best to consider the Quran to be composed in the native dialect of the audience it was originally addressed to, that is, the local dialect of Mecca and likely also Medina. This should be seen as strong, and independent, evidence for the location in which the Quran took its form, namely: the Hijaz. ${ }^{32}$

Taking the language of the Quran to be identical with the Hijazi vernacular is something that will strike many readers as familiar. After all, this has been the position of many classical Muslim authors on the one hand, and Karl Vollers (1906) on the other. It is worth exploring here how the current view should be seen in light of these views.

First, Vollers work should be seen in the context in which it was written. He advocated that the Quran was originally composed in the Hijazi vernacular, which he considered to be considerably closer to the features many modern dialects have today; he argued for a complete absence of the case system for example. To his mind, grammarians later 'upgraded' the text to be in line with Classical Arabic. This perspective now may strike us as flagrantly ahistorical-

32 Linguistically, Durie's (2018, 16f.) suggestion for the location of the Quran's dialect being in the Southern Levant is untenable. While Durie mostly correctly identifies several features of Quranic Arabic as also occurring either in Nabataean Arabic or in Safaitic, he brings no evidence that those take place in the Southern Levant to the exclusion of the Hijaz. The argument at best can therefore only serve as opening the possibility that the Quran is from either the Southern levant or the Hijaz. However, a more detailed analysis shows that the Southern Levantine option is less attractive, as Durie mixes freely linguistic features of distinct dialects of Arabic, and ignores clear isoglosses present in Quranic Arabic completely absent in the Southern Levant. Therefore, contrary to his claim, the linguistic evidence rather speaks in favour of the traditional narrative of the origin of the Quran, and speaks against more exotic suggestions that place the origins of the Quran in Petra or elsewhere in the Nabataean realm. 
it is clear that the text of the Quran was standardized long before the first grammarians became active, any reworking that requires a wholesale reworking of the rasm - which his work does - must be discarded.

However, Vollers' confusion about these facts in the beginning of the 2oth century can hardly be considered entirely his fault. At the time, access to early Quranic manuscripts was almost non-existent, and in fact even access to a print Quran that attempted to reproduce the Uthmanic rasm was not available. He therefore worked with the Flügel Quran of 1834, and indeed if one examines this text carefully and compares it against the reports of the Arabic grammarians and qirā? $\bar{a} t$ works one gets a strong impression that the text has been reworked towards a classical standard. The Flügel Quran has fully classicized spelling in keeping with the presumably Ottoman exemplar that was used for producing this print edition. Thus, all cases of $\bar{a}$ are spelled plene, the ?alif maqșürah of III- $y$ verbs before pronominal clitics is spelled with ?alif, not $y \bar{a}$ ?, and even postconsonantal hamzah is spelled with an Palif, such as in yas?alüna-ka as rather than the QCT's يسلونك. Indeed, the Quranic text had been reworked, but much later than Vollers himself imagined.

Further examples of Classicization in the Flügel Quran can be found in its representation of the reading tradition as well. While the Flügel Quran largely follows the reading of Hafș Yan fāșim many of the typical non-classical features of that reading had been edited out by Flügel. Thus Hafș' typical kufuwan and huzuwan instead of kufu?an and huzu?an have been systematically 'clas-

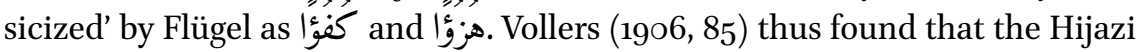
readings kufuwan and huzuwan had been edited out of the text. Many other typical features of Hafș' reading have been edited out of the text, thus ?ansāni$h u$ and Salay-hu !la $h$ - both likewise Hijazi readings-have been classicized to Pansāni-hi and Salay-hi lläh respectively. The Quranic text therefore was reworked, but not by the Arab grammarians but by a German orientalist.

Regardless of these issues in Vollers' work, the massive amount of disagreement between the Quranic readings on all kinds of forms, between the readers should have made his contemporaries aware that they did not know what the true language of the Quran was, and it is to his credit that he tried to answer this question. Moreover, reworking by the early Arabic readers can be uncovered through careful examination of the reading traditions, this will be discussed in more detail in the next two chapters.

Besides Vollers, also the medieval Muslim philologists seem to have considered the language of the Quran to be Hijazi. These statements - and especially those of al-Farrā? as presented in a translation by Kahle $(1947,79$ f. $)$ - that proclaim that the language of the Quran is the Qurashi dialect require more careful examination. Western scholars have usually taken the claims of the Quran as 
being Qurashi to be pious fabrications, as these scholars take it for granted that the language of the Quran was the 'poetic koiné' and not the dialect of the Qurayš. Thus, Rabin $(1955,26)$ says "had the Koran been composed in either the dialect of Quraish or in a "vulgar tongue", no amount of revision without altering the consonant outlines could have made it as similar to Classical [Arabic] as it is." 33

Zwettler $(1978,112)$ commenting on al-Farrā?'s explanation why the Qurashi dialect is the most correct says that "al-Farrā' has evoked here a fairly superficial picture of the classical 'arabiya (though, of course, not of the actual dialect of Qurayš)". Zwettler is commenting here on a tradition brought by al-Farrā? translated by Kahle of Sumar b. al-Xațțāb writing to ibn Maşūd (admonishing him to never say Sattā hịna instead of hattā ḥina again): "The Koran came down in the language of the Kuraish and it came not down in the language of the Hudhail. So, do you teach men to recite it in the language of the Kuraish and not in the language of Hudhail." Here the central view that the Quranic language is Qurashi is already found at the earliest possible date that we can expect to encounter it, with the second earliest grammarian whose works have come down to us.

Such commentaries have often been seen as a "dogma which equated the literary language with the Quraish dialect” (Rabin 1951, 21), but those familiar with the work of al-Farrā? should immediately see a problem with asserting the existence of such a dogma with this author. While al-Farrā? may have been in the business of extolling the qualities of the Qurayš dialect, from his work it should be obvious that this by no means meant that the Quran could only be read in the dialect of Qurayš, or that he equated the literary language he or his teachers used for recitation to the dialect of Qurayš. Al-Farrā? frequently discusses and approves of forms that are explicitly non-Qurashi even for recitation of the Quran (as we saw in chapter 3). He even transmits readings that by his standards are clearly non-Hijazi. One explicit example is that al-Farrā? (Lug $\bar{a} t$ ) reports that wariq is the Hijazi form, whereas warq is the Tamimi form and that al-RaSmaš and Yāșim read the Tamimi form bi-warqi-kum (Q18:19) and not the Hijazi form bi-wariqi-kum. ${ }^{34}$ This is presented as self-evident fact which required no explanation or apology.

The statement that the Quran was sent down in the dialect of Qurayš therefore should not be taken as a pious fabrication, nor should it be seen as a reflection of a dogma that equates the dialect of Qurayš to the 'poetic koiné'/classical

33 NB since Classical Arabic remains completely undefined, this statement is untestable.

34 Indeed, ŠuYbah Yan Yāṣim, of whom al-Farrā? is a transmitter reads it thus (Ibn Muğāhid, $389)$. 
arabic. It is clear that the language of recitation could be much broader than the language of revelation, and that this was not considered an issue. The language of the Quran as reflected in the QCT is evidently Hijazi and the fact that the readings do not reflect the dialect of the Qurayš does not disqualify this, the classical authors themselves did not consider it to be disqualifying either. 